\title{
TGF-beta receptor 2 downregulation in tumour-associated stroma worsens prognosis and high-grade tumours show more tumour-associated macrophages and lower TGF-betal expression in colon carcinoma: a retrospective study
}

\author{
David Bacman ${ }^{1}$, Susanne Merkel ${ }^{2}$, Roland Croner ${ }^{2}$, Thomas Papadopoulos ${ }^{1}$, \\ Wolfgang Brueckl ${ }^{3}$ and Arno Dimmler*4
}

\begin{abstract}
Address: ${ }^{1}$ Institute of Pathology, University of Erlangen-Nuremberg, Germany, ${ }^{2}$ Department of Surgery, University of Erlangen-Nuremberg, Germany, ${ }^{3}$ Department of Internal Medicine I, University of Erlangen-Nuremberg, Germany and ${ }^{4}$ Institute of Pathology, St. Vincentius hospital, Karlsruhe, Germany

Email: David Bacman - david_bacman2@yahoo.de; Susanne Merkel - susanne.merkel@chir.imed.uni-erlangen.de;

Roland Croner - roland.croner@chir.imed.uni-erlangen.de; Thomas Papadopoulos - thomas.papadopoulos@patho.imed.uni-erlangen.de; Wolfgang Brueckl - wolfgang.brueckl@med1.imed.uni-erlangen.de; Arno Dimmler* - arno.dimmler@vincentius-ka.de

* Corresponding author
\end{abstract}

Published: 10 August 2007

BMC Cancer 2007, 7:156 doi:10.1186/147I-2407-7-156

This article is available from: http://www.biomedcentral.com//47/-2407/7//56

(C) 2007 Bacman et al; licensee BioMed Central Ltd.

This is an Open Access article distributed under the terms of the Creative Commons Attribution License (http://creativecommons.org/licenses/by/2.0), which permits unrestricted use, distribution, and reproduction in any medium, provided the original work is properly cited.
Received: 16 December 2006

Accepted: 10 August 2007

\begin{abstract}
Background: Histological phenotype and clinical behaviour of malignant tumours are not only dependent on alterations in the epithelial cell compartment, but are affected by their interaction with inflammatory cells and tumour-associated stroma. Studies in animal models have shown influence of tumour-associated macrophages (TAM) on histological grade of differentiation in colon carcinoma. Disruption of transforming growth factor beta (TGF-beta) signalling in tumour cells is related to more aggressive clinical behaviour. Expression data of components of this pathway in tumour-associated stroma is limited.
\end{abstract}

Methods: Tissue micro arrays of 310 colon carcinomas from curatively resected patients in UICC stage II and III were established. In a first step we quantified amount of CD68 positive TAMs and expression of components of TGF-beta signalling (TGF-beta I, TGF-beta receptors type I and 2, Smad 3 and 4) in tumour and associated stroma. Further we analyzed correlation to histological and clinical parameters (histological grade of differentiation (low-grade (i.e. grade I and 2) vs. high-grade (i.e. grade 3 and 4)), lymph node metastasis, distant metastasis, 5 year cancer related survival) using Chi-square or Fisher's exact test, when appropriate, to compare frequencies, Kaplan-Meier method to calculate 5-year rates of distant metastases and cancer-related survival and log rank test to compare the rates of distant metastases and survival. To identify independent prognostic factors Cox regression analysis including lymph node status and grading was performed.

Results: High-grade tumours and those with lymph node metastases showed higher rates of TAMs and lower expression of TGF-beta I. Loss of nuclear Smad4 expression in tumor was associated with presence of lymph node metastasis, but no influence on prognosis could be demonstrated. Decrease of both TGF-beta receptors in tumour-associated stroma was associated with increased lymph node metastasis and shorter survival. Stromal TGF-beta receptor 2 expression was an independent prognostic factor for cancer related survival.

Conclusion: Histological phenotype and clinical behaviour of colon cancer is not only influenced by mutational incidents in tumour cells but also affected by interaction of tumour tissue with inflammatory cells like macrophages and associated stroma and TGF-beta signalling is one important part of this crosstalk. Further studies are needed to elucidate the exact mechanisms. 


\section{Background}

Tumours do not exclusively consist of neoplastic epithelial cells, but are also accompanied by a stromal compartment composed of a variety of non-malignant cells, such as fibroblasts, inflammatory cells, and endothelial cells, as well as extracellular elements $[1,2]$ Nonetheless in the past cancer research has been focused primarily on oncogenic events in tumour cells. It has, however, become increasingly clear that the tumour environment plays an important role in malignant disease, and a correlation between (chronic) inflammation and human predisposition to carcinogenesis has been demonstrated in several malignancies [3-5].

The majority of leukocytes that infiltrate the neoplastic stroma consist of macrophages, which are referred to as tumour-associated macrophages (TAMs) $[1,4,6]$. Clinical observations have shown that the presence of abundant TAMs can be associated with malignant behaviour in breast, prostatic, ovarian, and cervical carcinomas [4]. For other types of cancer, such as gastric, lung, and colorectal carcinomas, opposing data have been reported[4,7-9]. Thus, the biological significance and possible clinical implications of TAMs' presence are not yet fully understood.

Maintenance of epithelial tissues needs the stroma. When the epithelium changes, the stroma inevitably follows. Crosstalk between tumour and stromal compartment is based on several signalling pathways. One important cytokine in this context is transforming growth factor beta (TGF- $\beta$ ). The TGF- $\beta$ superfamily of secreted polypeptides consists of three $25 \mathrm{kDa}$-proteins (TGF- $\beta 1,2$ and 3 ) and regulates cell proliferation, differentiation, motility, apoptosis and extracellular matrix formation in a variety of different cell types [10-12]. TGF- $\beta$ serves as a tumour suppressor pathway in the normal colon by inhibiting cell proliferation and inducing apoptosis [13-15]. During late stages of colorectal carcinogenesis, TGF- $\beta$ serves as a tumour promoter $[16,17]$ and is often over expressed. A high expression level of TGF- $\beta$ in the primary tumour is associated with advanced stages[18], tumour recurrence [19], and decreased survival[18].

The TGF- $\beta$ signal is transduced by a pair of transmembrane serine-threonine kinase receptors[11]. TGF- $\beta$ binds primarily to TGF- $\beta$-R2 receptor homodimers, which then form heterotetrameric complexes with two TGF- $\beta$-R1 molecules. As a consequence, the TGF- $\beta$-R2 kinase phosphorylates TGF- $\beta-R 1$, thereby activating its serine-threonine kinase. In response to receptor activation, two cytosolic proteins, Smad2 and Smad3, become transiently associated with and phosphorylated by the TGF- $\beta$-R1 kinase. After their activation, Smad2 and Smad3 form heteromeric complexes with a third homologue, Smad4. These complexes are translocated to the nucleus, bind to DNA in a sequence-specific manner, and regulate gene transcription[11]. The resulting repression of $\mathrm{c}-m y c$ and induction of cyclin-dependent kinase inhibitors as well as cdc25A phosphatase lead to $G_{1}$ phase cell cycle arrest.

Most colorectal cancers escape the tumour suppressor effects of TGF- $\beta$ as demonstrated by their resistance to the antiproliferative and apoptotic effects of TGF- $\beta[16,17]$. The molecular mechanisms by which colorectal cancers escape the tumour suppressor effects of TGF- $\beta$ are an area of active investigation. A subset of colorectal cancers has been shown to have mutations or down-regulation of the type 1 receptor [20], type 2 receptor [21], Smad2 [22,23] and Smad4 [24-26].

Most studies so far focussed on alterations of the TGF- $\beta$ pathway in the tumour cells. In the present study we investigated in addition to tumour-associated macrophages alterations of this signalling in tumour-associated desmoplastic stroma and their relation to histological tumour grade, regional and distant metastasis rates and survival in a group of colon carcinoma patients that underwent colon resection.

\section{Methods \\ Tumour samples}

Cases of colon adenocarcinomas were retrieved retrospectively from the files of the Department of Pathology at the University of Erlangen-Nuremberg, Germany. The specimen had been formalin-fixed, paraffin-embedded and tumour diagnosis made on haematoxylin and eosin (HE) sections. In the present study 310 tumour samples of patients were included, which underwent radical resection with formal regional lymph node dissection between 1991 and 2001 and received complete surgical resection of their colon carcinoma on clinical and pathohistological examination. Only solitary colon carcinomas except appendix tumours were included. Further exclusion criteria were: anamnestic or synchronous other malignant tumours, known familial adenomatous polyposis, colitis ulcerosa or Crohn's disease, neoadjuvant therapy, synchronous distant metastases, emergency operation, perioperative death and unknown tumour stage at the end of follow up. Clinical data is summarized in table 1. The study was carried out in compliance with the Helsinki Declaration. Ethics Committee, Faculty of Medicine, University of Erlangen-Nuremberg approved research on anonymized archived tumor material of patients in a general statement from January 24th, 2005.

\section{Tissue micro array technique}

A map of the receiver blocks was prepared with coordinates for each sample to correctly identify the tumour samples. Under a microscope nonnecrotic carcinoma 
Table I: Clinical data of included colon carcinoma patients

\begin{tabular}{|c|c|}
\hline \multicolumn{2}{|l|}{ patient data } \\
\hline number of patients & $\mathrm{n}=310$ \\
\hline of these: male & $n=189(61 \%)$ \\
\hline female & $n=121(39 \%)$ \\
\hline median age & 64 y (range $28-91$ y) \\
\hline median follow up & $91 \mathrm{mo}$ (range I-I77 mo) \\
\hline adjuvant chemotherapy & $n=48(16 \%)$ \\
\hline \multicolumn{2}{|l|}{ tumour site } \\
\hline caecum & $\mathrm{n}=31(10.0 \%)$ \\
\hline colon ascendens & $\mathrm{n}=5 \mathrm{I}(16.5 \%)$ \\
\hline flexura hepatica & $\mathrm{n}=2 \mathrm{l}(6.8 \%)$ \\
\hline colon transversum & $\mathrm{n}=32(10.3 \%)$ \\
\hline flexura lienalis & $\mathrm{n}=15(4.8 \%)$ \\
\hline colon descendens & $\mathrm{n}=14(4.5 \%)$ \\
\hline colon sigmoideum & $n=146(47.1 \%)$ \\
\hline \multicolumn{2}{|c|}{ tumour stage (UICC) or lymph node metastasis } \\
\hline II or NO & $\mathrm{n}=178(57.4 \%)$ \\
\hline III or $\mathrm{N}+$ & $\mathrm{n}=132(42.6 \%)$ \\
\hline \multicolumn{2}{|l|}{ grading } \\
\hline low-grade (GI and G2) & $\mathrm{n}=257(82.9 \%)$ \\
\hline high-grade (G3 and G4) & $\mathrm{n}=53(17.1 \%)$ \\
\hline \multicolumn{2}{|l|}{ depth of invasion } \\
\hline pT2 & $\mathrm{n}=24(7.7 \%)$ \\
\hline pT3 & $\mathrm{n}=255(82.3 \%)$ \\
\hline PT4 & $\mathrm{n}=31(10.0 \%)$ \\
\hline distant metastasis after 5 years follow up & $\mathrm{n}=62(20.0 \%)$ \\
\hline
\end{tabular}

areas and surrounding areas of immediately adjacent desmoplastic stroma were marked with an indelible pen on the HE whole section of each donor block.

The tissue micro arrayer (Beecher Instruments, Woodland, USA) was used as follows: cores of $0.6 \mathrm{~mm}$ diameter were punched from the donor blocks and positioned in a recipient paraffin array block in smaller holes of $0.4 \mathrm{~mm}$ for best adhesion of the samples to the array block. Three cores of tonsil tissue were positioned on the upper left corner of each recipient block for correct orientation on the array of the recipient block. The array blocks were then incubated for $30 \mathrm{~min}$ at $37^{\circ} \mathrm{C}$ to improve adhesion between cores and paraffin of the recipient block. Afterwards the blocks were cut with a standard microtome (Microm, Heidelberg, Germany).

\section{Immunohistochemistry}

Sections of $5 \mu \mathrm{m}$ from the fourteen tissue arrays were cut onto silane-treated Super Frost slides (CML, Nemours, France) and left to dry overnight. The slides were deparaffinized in xylene and rehydrated in pure ethanol. Endogenous peroxidase was blocked using $3 \%$ hydrogen peroxide in methanol for $30 \mathrm{~min}$. The slides were then placed in a microwave oven in citrate buffer (TGF- $\beta 1$, TGF- $\beta$-R1, TGF- $\beta$-R2, Smad3, CD68) for $45 \mathrm{~min}$ at 120 to $85^{\circ} \mathrm{C}$ for antigen retrieval with a subsequent biotinstreptavidin-peroxidase detection technique or in TRS6 (DAKO, Hamburg, Germany) buffer (Smad4) at the same processing conditions with subsequent tyramide signal amplification coupled alkaline phosphatase (DAKO, Hamburg, Germany) -Fast Red (Sigma-Aldrich, Munich, Germany) detection technique. All slides were then proc- 
essed manually. Antibodies to TGF- $\beta 1$ (mouse antihuman monoclonal, clone TGFB17, dilution 1:20, Novo Castra, Newcastle upon Tyne, Great Britain), TGF- $\beta$-R1 (mouse anti-human monoclonal, clone 8A11, dilution 1:100, Novo Castra, Newcastle upon Tyne, Great Britain), TGF- $\beta$-R2 (goat anti-human polyclonal, AF-241-NA, dilution 1:100, Wiesbaden, Germany), Smad3 (rabbit antihuman polyclonal, 51-500, dilution 1:200, Zymed, San Francisco, USA), Smad4 (mouse anti-human monoclonal, sc-7966, dilution 1:50, Santa Cruz Biotechnology, Heidelberg, Germany), CD68 (mouse anti-human monoclonal, clone PG-M1, dilution 1:200, DAKO, Hamburg, Germany) were used. The slides were counterstained with Mayer's haemalaun. To exclude non-specific reactions of secondary antibodies or the different detection systems control specimen were processed without primary antibodies. In the CD68 staining four categories of macrophage infiltration of the tumour tissue were assessed (none (0), mild (1), intermediate (2), strong (3), see fig. $1)$. In the TGF- $\beta 1$ staining four degrees of cytoplasmatic staining intensity (none (0), mild (1), medium(2), strong (3), fig. 1) in tumour and surrounding stroma were assessed separately. For the TGF- $\beta$-R1 and TGF- $\beta$-R2 membranous staining the same four categories were applied (fig. 1). Presence or absence of nuclear and cytoplasmatic staining was assessed for Smad 3 and 4 in tumour and surrounding stroma (for examples [see Additional file 1]).

\section{Statistical analysis}

The Kaplan-Meier method was used to calculate 5-year rates of distant metastases and cancer-related survival. The log rank test was used to compare the rates of distant metastases and survival. To identify independent prognostic factors Cox regression analysis including lymph node status and grading was performed. To compare frequencies Chi-square test, or Fisher's exact test when appropriate, was used. A p-value of less than 0.05 was considered to be significant. All analyses were performed using the statistical software SPSS for Windows Version 13 (SPSS Inc., Chicago, USA).

\section{Results}

The results are summarized in table 2.

\section{TAMs}

Macrophages in tumour-associated stroma were more abundant than those infiltrating tumour tissue (mean score 1.8 vs. 0.5 ). We found significantly higher levels of tumour-associated macrophages in high-grade tumours $(\mathrm{p}<0.001)$ and tumours with lymph node metastases ( $\mathrm{p}$ $=0.019$ ). $58 \%$ (167 of 287 ) of tumours with no or only mild infiltration by TAMs compared to $45 \%$ ( 9 of 20) of tumours showing intermediate and strong infiltration had no lymph node metastases. There were no significant differences in 5-year survival (87\% vs. $80 \%)$ or distant metastases ( $19.4 \%$ vs. $30.0 \%$ ) between the two groups ( $\mathrm{p}$ $=0.261$ and $\mathrm{p}=0.241$ respectively) .

\section{Components of TGF- $\beta$ pathway in tumour tissue}

In 296 of 308 tumours (96\%) expression of TGF- $\beta 1$ could be demonstrated. Low-grade tumours showed higher TGF- $\beta 1$ expression ( $\mathrm{p}=0.009$; mean expression level 1.40 for low-grade vs. 0.91 for high-grade tumours). No correlation between TGF- $\beta 1$ expression and lymph node metastasis, cancer related survival or distant metastasis could be demonstrated.

Only few tumours showed expression of TGF- $\beta$ receptors ( $27 \%$ or 84 of 309 for type $1 ; 5 \%$ or 14 of 295 for type 2). The rate of receptor expression was not linked to histological grade, regional or distant metastasis or survival.

In the majority of tumours (nuclear or cytoplasmatic) expression of Smad3 (91\%; 279 of 309 tumours) and Smad4 (100\% or all 305 tumours) was found. Most tumours showed nuclear expression of Smad3 (57\%; 176 of 309) and Smad4 (86\%; 261 of 305), but no correlation to histological grade could be demonstrated. More nodal positive tumours (93\% or 122 of 131 ) than cases without lymph node metastasis $(80 \%$ or 139 of 174 ) showed nuclear Smad4 expression ( $\mathrm{p}=0.004)$. No correlation was found between expression of Smads and distant metastasis or survival.

\section{Components of TGF- $\beta$ pathway in tumour-associated stroma}

Expression of TGF- $\beta 1$ in tumour-associated stroma could not be demonstrated. Expression of TGF- $\beta$ receptors and Smads in stroma was restricted to spindled and sometimes stellar stromal cells apparently representing fibroblasts and myofibroblasts. In most cases TGF- $\beta$ receptors were expressed in the tumour-associated stroma $(60 \%$ or 188 of 310 for type $1 ; 60 \%$ or 186 of 309 for type 2 ). For both receptors no correlation to histological grade was found. Higher TGF- $\beta$ receptor expression in stroma was associated with significant decrease of nodal positive tumours (table 2, $\mathrm{p}=0.033$ for type 1 and $\mathrm{p}=0.001$ for type 2). This was partially reflected by significantly better 5 -year cancer related survival for receptor positive compared to negative cases in the nodal positive group (type 1: $86 \%$ vs. $69 \% ; \mathrm{p}=0.011$ and type $2: 83 \%$ vs.76\%; $\mathrm{p}=$ $0.032)$. TGF- $\beta$ receptor expressing cases showed a trend towards lower rates of distant metastasis, although this difference was not significant (table $2 ; 24.5 \%$ vs. $12.3 \%$; p $=0.072$ for type 1 and $25.4 \%$ vs. $16.6 \%, p=0.087$ for type 2).

Nuclear expression in the stroma was detected in $46 \%$ (143 of 310) of tumours for Smad3 and 97\% (301 of 309) 


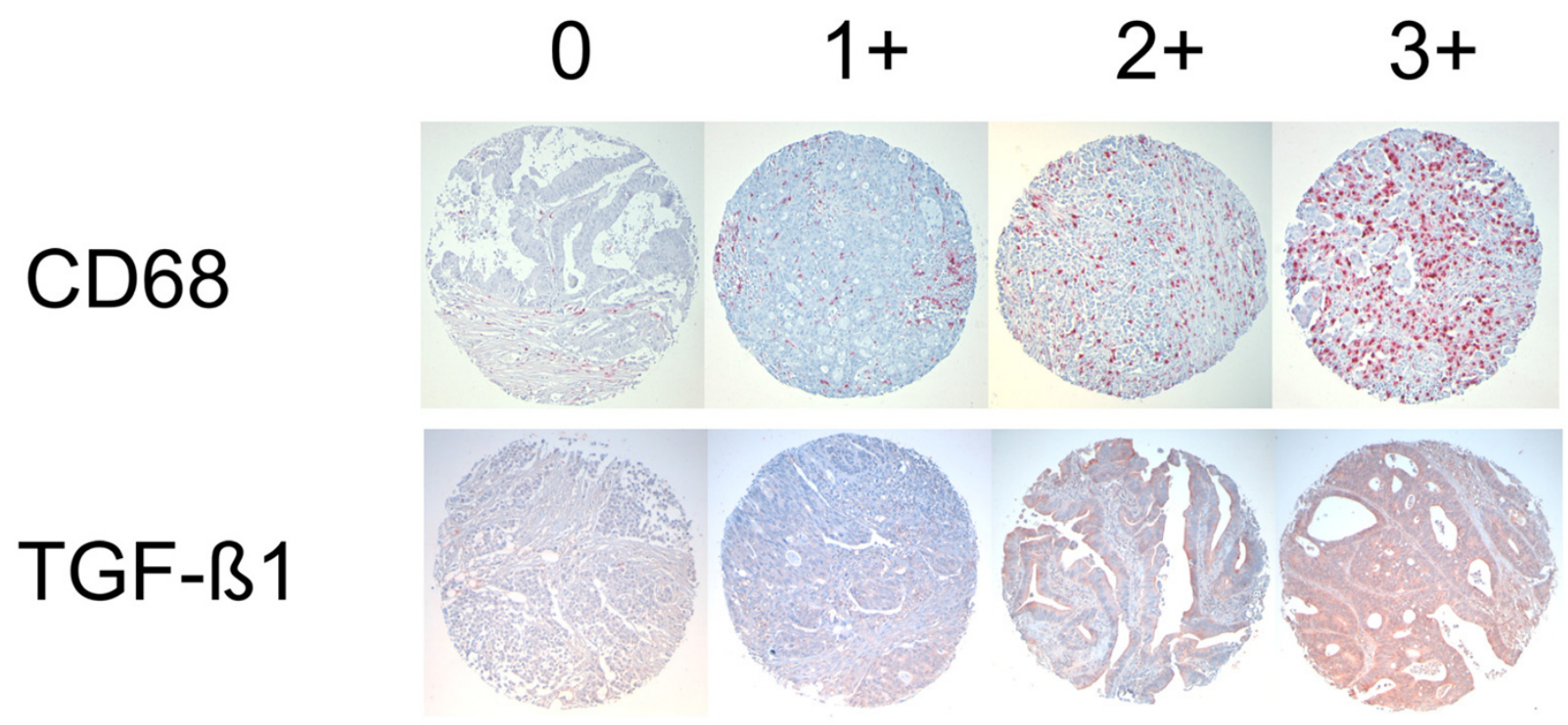

\section{TGF-ß-R2 in tumor}
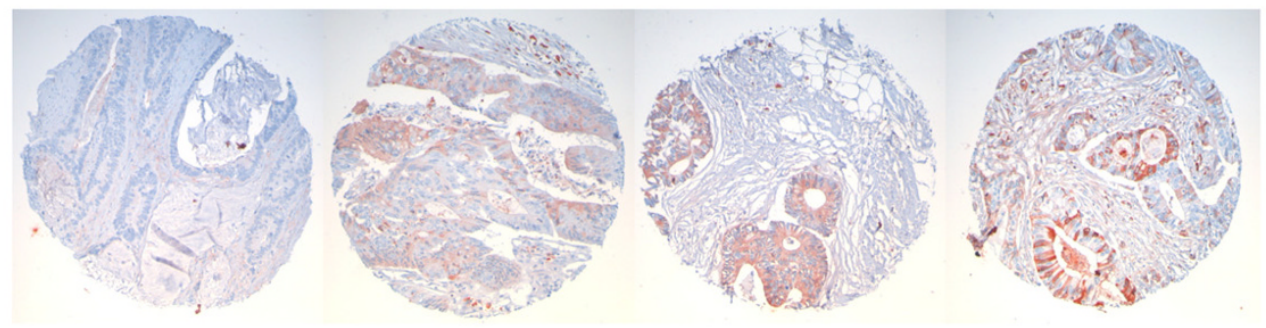

\section{TGF-ß-R2 in stroma}

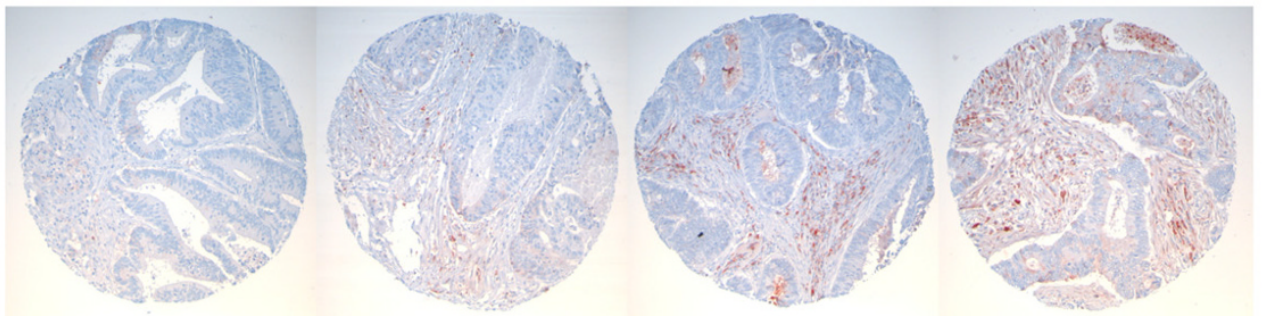

Figure I

Immunohistochemical analysis of tumor and associated stroma. Examples for degree of TAM infiltration in CD68 staining and levels of expression of TGF- $\beta 1$ and TGF- $\beta-R 2$ in tumour and associated stroma. Note change of differentiation grade with increase in TAMs.

for Smad4. No correlation to histological grade, local and distant metastasis or survival could be demonstrated.

\section{Multivariate analysis}

In univariate analysis using log rank test presence of lymph node metastasis (identical to tumour stage: 5-year cancer-related survival rate: N0 or II: $92.1 \%$ vs. N+ or III: $79.5 \%$, p $<0,001$, table 3), vessel infiltration (V0: $89.0 \%$ vs. V1: $58.3 \%, \mathrm{p}<0,001)$ and TGF- $\beta$-R2 expression in tumour-associated stroma (negative: $82.3 \%$ vs. positive: $89.3 \%, p=0,003$ ) showed statistically significant correlation to cancer-related survival, whereas for all other factors no association could be demonstrated (see table 3). On multivariate analysis using Cox regression analysis besides vessel infiltration and lymph node status expression of TGF- $\beta-R 2$ in the stroma (RR 2.2, 95\%CI 1.2-3.8, p 
Table 2: Content of tumour-associated macrophages and expression of TGF- $\beta$ components in tumour and -associated stroma

\begin{tabular}{|c|c|c|c|c|c|c|c|c|c|c|c|c|c|c|c|c|c|c|}
\hline \multirow{2}{*}{$\begin{array}{c}\text { tumour } \\
\mathrm{n}\end{array}$} & \multicolumn{2}{|c|}{ TAMs } & \multicolumn{4}{|c|}{ TGF- $\beta$ I } & \multicolumn{2}{|c|}{ TGF- $\beta-R$ I } & \multicolumn{4}{|c|}{ TGF- $\beta-R 2$} & \multicolumn{2}{|c|}{ Smad3 } & \multicolumn{4}{|c|}{ Smad4 } \\
\hline & $\begin{array}{l}\text { low } \\
(0-1)\end{array}$ & $\begin{array}{l}\text { high } \\
(2-3)\end{array}$ & $\stackrel{P}{P}$ & $\begin{array}{l}\text { low } \\
(0-1)\end{array}$ & $\begin{array}{l}\text { high } \\
(2-3)\end{array}$ & $\underset{\text { value }}{P}$ & $\begin{array}{l}\text { low } \\
(0-1)\end{array}$ & $\begin{array}{l}\text { high } \\
(2-3)\end{array}$ & $\stackrel{P}{\mathrm{P}}$ & neg. & pos. & $\underset{\text { value }}{P}$ & neg. & pos. & $\underset{\text { value }}{\mathrm{P}}$ & neg. & pos. & $\underset{\text { value }}{P}$ \\
\hline low-grade & 248 & 7 & $<0.00$ & 165 & 90 & 0.009 & 239 & 16 & 0.148 & 245 & 10 & 0.278 & 111 & 146 & 0.907 & 39 & 214 & 0.295 \\
\hline high-grade & 39 & 13 & & 44 & 9 & & 47 & 7 & & 50 & 4 & & 22 & 30 & & 5 & 47 & \\
\hline No & 167 & 9 & 0.019 & 113 & 63 & 0.202 & 163 & 14 & $0.58 \mathrm{I}$ & 167 & 10 & 0.630 & 79 & 99 & 0.579 & 35 & 139 & 0.004 \\
\hline $\mathrm{N}+$ & 120 & II & & 96 & 36 & & 123 & 9 & & 128 & 4 & & 54 & 77 & & 9 & 122 & \\
\hline 5 ycrs & 87.0 & 80.0 & 0.261 & 85.6 & 88.8 & 0.459 & 86.4 & 87.0 & 0.787 & 87.0 & 78.6 & 0.631 & 86.1 & 86.6 & 0.991 & 92.5 & 85.4 & 0.896 \\
\hline $5 \mathrm{ydm}$ & 19.4 & 30.0 & 0.241 & 18.7 & 22.6 & 0.463 & 19.9 & 17.4 & 0.851 & 19.9 & 21.4 & 0.701 & 19.5 & 19.9 & 0.795 & 17.3 & 20.7 & 0.419 \\
\hline stroma & & & & & & & TGF & $3-R I$ & & TGF & $3-R 2$ & & & & & Sm & & \\
\hline $\mathrm{n}$ & $\begin{array}{l}\text { low } \\
(0-1)\end{array}$ & $\begin{array}{l}\text { high } \\
(2-3)\end{array}$ & $\underset{\text { value }}{P}$ & $\begin{array}{l}\text { low } \\
(0-I)\end{array}$ & $\begin{array}{l}\text { high } \\
(2-3)\end{array}$ & $\underset{\text { value }}{P}$ & $\begin{array}{l}\text { low } \\
(0-1)\end{array}$ & $\begin{array}{l}\text { high } \\
(2-3)\end{array}$ & $\underset{\text { value }}{\mathrm{P}}$ & neg. & pos. & $\underset{\text { value }}{\mathrm{P}}$ & neg. & pos. & $\underset{\text { value }}{\mathrm{P}}$ & neg. & pos. & $\underset{\text { value }}{P}$ \\
\hline low-grade & 152 & 104 & 0.134 & 256 & 0 & n.a. & 162 & 94 & 1.000 & 98 & 158 & 0.229 & 140 & 117 & 0.653 & 7 & 249 & 1.000 \\
\hline high-grade & 26 & 28 & & 52 & 0 & & 34 & 20 & & 25 & 28 & & 27 & 26 & & 1 & 52 & \\
\hline No & 59 & 39 & 0.141 & 176 & 0 & n.a. & 102 & 76 & 0.033 & 56 & 121 & 0.001 & 98 & 80 & 0.627 & 5 & 172 & 1.000 \\
\hline $\mathrm{N}+$ & 119 & 93 & & 132 & 0 & & 94 & 38 & & 67 & 65 & & 69 & 63 & & 3 & 129 & \\
\hline 5 ycrs & 84.1 & 87.8 & 0.897 & 86.4 & n.a. & n.a. & 84.7 & 89.5 & 0.245 & 82.3 & 89.3 & 0.003 & 87.5 & 85.4 & 0.753 & 83.3 & 86.5 & 0.812 \\
\hline $5 \mathrm{ydm}$ & 12.6 & 20.0 & 0.643 & 20.7 & n.a. & n.a. & 24.5 & 12.3 & 0.072 & 25.4 & 16.6 & 0.087 & 21.0 & 18.9 & 0.392 & 14.3 & 20.2 & 0.582 \\
\hline
\end{tabular}

5 ycr: 5 year cancer related survival (\%); 5 ydm: 5 year rate of distant metastasis (\%); n.a.: not available.

$=0.007$, table 3) was an independent prognostic factor for cancer-related survival as reflected in Kaplan-Meier survival curve (see Fig. 2).

\section{Discussion}

Macrophage functions are profoundly affected by microenvironmental signals and can range from powerful induction of inflammatory responses to immunosuppression [27]. Although it has been demonstrated previously

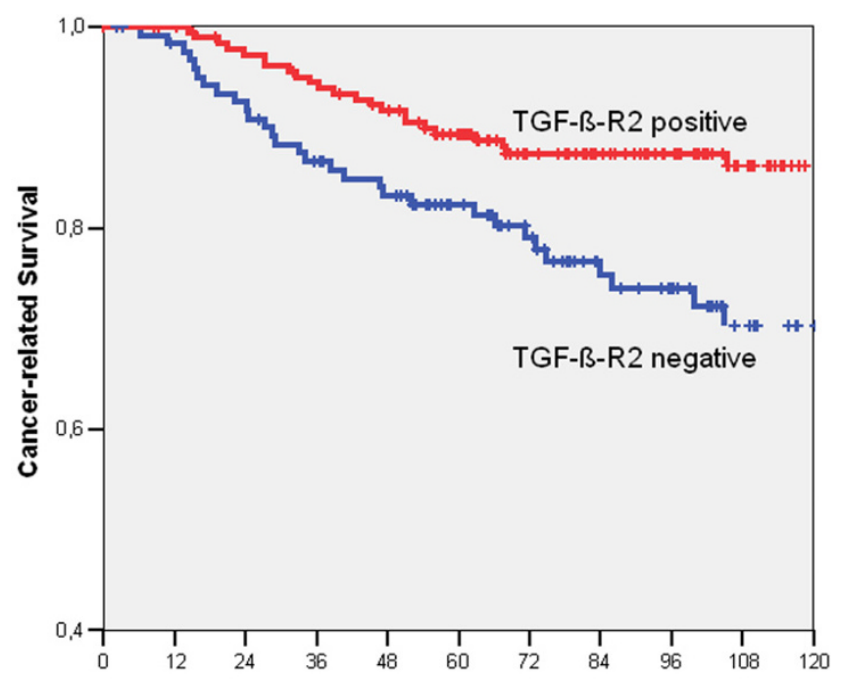

Figure 2

Kaplan-Meier survival curve for TGF- $\beta-R 2$ expression in tumor-associated stroma. Cancer-related survival of colon carcinoma patients according to TGF- $\beta-\mathrm{R} 2$ expression in tumour-associated stroma. that macrophages are capable of killing tumour cells in vitro and in vivo, evidence is now emerging in support of a tumour-promoting role for macrophages, and it has recently been hypothesized that macrophages, residing within neoplastic tissues, are educated by tumour cells to perform auxiliary oncogenic functions such as matrix break-down and induction of angiogenesis [27-30]. In the present study we found higher levels of TAMs in highgrade tumours and tumours with lymph node metastasis. Although there was a trend towards lower rates of distant metastasis and better survival rates in TAM rich tumours, this difference was not statistically significant. As this group accounts for less than $7 \%$ of tumours in our study this result might not be reproducible in larger series. Nonetheless several observations could explain these apparently contradictory effects of macrophages in disease outcome. In a recent experimental study the level of macrophage accumulation was found to correlate with macrophage functionality: high-level secretion of monocyte chemoattractant protein-1 (MCP-1) resulted in massive infiltration of macrophages with subsequent tumour regression. By contrast, low-level secretion of MCP-1 led to moderate infiltration of macrophages and melanoma progression [31]. Second, macrophage activity may alter over time as a consequence of tumour-induced immune dysfunction, since nitric oxide production, which is a major effector molecule for tumour cell killing, was suppressed in macrophages of tumour-bearing mice [32]. Third, a conceptual framework referred to as the so called macrophage balance hypothesis has been proposed, defining two different macrophage populations ranging from polarized potent killer/effector M1 cells to alternatively activated M2 macrophages with tumour-promoting characteristics. In a recently published study, the presence 
Table 3: Results of univariate and multivariate analysis

\begin{tabular}{|c|c|c|c|c|c|}
\hline & \multicolumn{5}{|c|}{ univariate analysis } \\
\hline & score & $\mathrm{n}$ & 5 year survival rate & SE & $P$ value \\
\hline \multirow[t]{3}{*}{ pT } & 2 & 24 & 100 & & 0.226 \\
\hline & 3 & 255 & 85.6 & 2.2 & \\
\hline & 4 & 31 & 83.0 & 6.9 & \\
\hline \multirow[t]{2}{*}{ grading } & low-grade & 257 & 86.9 & 2.2 & 0.446 \\
\hline & high-grade & 53 & 84.8 & 5 & \\
\hline lymph node status & NO or II & 178 & 92.1 & 2.1 & $<0.001$ \\
\hline or stage & $\mathrm{N}+$ or III & 132 & 79.5 & 3.5 & \\
\hline \multirow[t]{2}{*}{ vessel infiltration } & Vo & 285 & 89.0 & 1.9 & $<0.001$ \\
\hline & VI & 24 & 58.3 & 10.1 & \\
\hline \multirow[t]{2}{*}{ chemotherapy } & applied & 261 & 87.1 & 2.1 & 0.700 \\
\hline & not applied & 49 & 83.5 & 5.3 & \\
\hline \multirow{2}{*}{ TGF- $\beta$ I in tumour } & low $(0-1)$ & 209 & 85.5 & 2.5 & 0.462 \\
\hline & high (2-3) & 99 & 88.6 & 3.2 & \\
\hline \multirow[t]{2}{*}{ Smad3 in tumour } & negative & 133 & 88.1 & 2.9 & $0.94 I$ \\
\hline & positive & 176 & 85.3 & 2.7 & \\
\hline \multirow[t]{2}{*}{ Smad4 in tumour } & negative & 44 & 92.5 & 4.2 & 0.896 \\
\hline & positive & 261 & 85.4 & 2.2 & \\
\hline \multirow[t]{2}{*}{ TGF- $\beta-R I$ in stroma } & negative & 122 & 83.8 & 3.4 & 0.121 \\
\hline & positive & 188 & 88.3 & 2.4 & \\
\hline \multirow[t]{4}{*}{ TGF- $\beta$ R2 in stroma } & negative & 123 & 82.3 & 3.5 & 0.003 \\
\hline & positive & 186 & 89.3 & 2.3 & \\
\hline & \multicolumn{5}{|c|}{ multivariate analysis } \\
\hline & score & $\mathrm{n}$ & relative risk $R R$ & $\begin{array}{l}95 \% \text { confidence } \\
\text { intervall }\end{array}$ & $P$ value \\
\hline \multirow[t]{2}{*}{ TGF- $\beta$ R2 in stroma } & negative & 122 & 1 & & \\
\hline & positive & 186 & 2.2 & $1.2-3.8$ & 0.007 \\
\hline \multirow[t]{2}{*}{ lymph node status } & No & 177 & 1 & & \\
\hline & $\mathrm{N}+$ & $13 \mid$ & 2.1 & $1.2-3.8$ & 0.012 \\
\hline \multirow[t]{2}{*}{ vessel infiltration } & vo & 284 & 1 & & \\
\hline & VI & 24 & 4.1 & $2.1-7.9$ & $<0.001$ \\
\hline
\end{tabular}

of macrophages directed tumours towards a histologically more malignant phenotype characterized by extensive stromal reaction, disorganized matrix deposition, and neovascularization [33]. Nonetheless, depletion of macrophages deprived tumour inhibitory functions as well, resulting in enhanced growth and decreased survival, emphasizing the complexity of the proposed macrophage balance. We think balance between the following actions of tumour-associated macrophages could account for some observations in the present study: At the primary tumour site macrophage dependent and cytokine mediated promoting activity might increase local infiltrative growth, enhancement of lymphangiogenesis and lymphatic vessel infiltration. On the other hand tumouricidal activity of macrophages might be restricted to single and isolated tumour cells on invasion front and founder cells of early hematogenic metastases. Reducing the number of macrophages per se, which has been proposed as a therapeutic strategy, may therefore not constitute the most optimal approach. However, specifically counteracting tumour-promoting characteristics and/or enhancing macrophage tumouricidal activity might be promising for future therapies. The second question we addressed in this study was whether alterations in TGF- $\beta$ signalling are related to histological tumour grade and clinical behaviour of colon cancers. First we analyzed important factors of TGF- $\beta$ signalling pathway in the epithelial component of the tumours. Immunostainable TGF- $\beta 1$ has been detected in the malignant epithelial cells in the majority of our investigated cases of colon carcinomas and expression was shown to be higher in low-grade tumours, as shown recently [34], whereas we found no correlation to lymph node metastases, tumour stage or survival, although there was a non-significant trend towards lower TGF- $\beta 1$ expression in tumours with regional lymph node metastases. This is in contrast to studies, where TGF- $\beta 1$ overexpression in advanced stages of colorectal cancers has been reported and the intensity of the staining seems 
to correlate with advancing stages of tumour progression[35,36]. However, interpretation of these studies is complicated by difficulties associated with distinguishing the biologically inactive, latent form of TGF- $\beta 1$ from its activated form.

Most tumours in the present study showed no detectable TGF- $\beta$ receptor expression. The loss of TGF- $\beta$ receptor expression in colon cancer either through mutation or downregulation has been reported $[20,21]$, but like in our study no correlation to histological grade or clinical outcome was found[37]. In contrast to loss of TGF- $\beta$ receptors in tumour tissue we found frequent activation of Smad signalling indicated by nuclear expression of Smad3 and Smad4 in tumour and surrounding stroma, but only nuclear expression of Smad4 in the malignant epithelial component was correlated to presence of lymph node metastasis. Although experimental data suggest tumour suppressive effects of functionally active Smad4[38,39] and loss of Smad4 in colorectal cancer is associated with advanced stage disease, presence of lymph node metastasis and poor prognosis [40-43], others reported retained Smad4 expression in high-grade colorectal carcinoma and suggested loss of Smad4 is a late event in colorectal carcinogenesis [44]. In our study no influence of reduced Smad4 expression on prognosis was found. A possible explanation could be that in our study nodal positive cases (i.e. stage III patients) had an excellent 5 year survival of almost $80 \%$ indicating good local tumor control. The reduction of local recurrences possibly through extended lymphadenectomy could eliminate the prognostic influence of reduced Smad4. Activation of Smad signalling in our cases as indicated by frequent nuclear expression in the absence of TGF- $\beta$-R expression might occur primarily through TGF- $\beta$ independent mechanisms, e.g. activin signalling [45]. Most authors so far focused primarily on the malignant epithelial component in tumours, so expression data of components of TGF- $\beta$ pathway in tumour-associated stroma is rare. Unlike others [21] we found no expression of TGF- $\beta 1$ in stroma. In our study frequent nuclear expression of Smads showed no correlation to tumour grade or clinical outcome. The most important finding in our study was an association of expression of both TGF- $\beta$ receptors to presence of regional metastases. In patients with regional metastasized tumours decreased receptor expression in tumour-associated stroma was associated with shorter survival, whereas incidence of distant metastases showed only minor nonsignificant increase. Most importantly besides the wellestablished influence of lymph node metastasis and vessel infiltration on cancer-related survival in our study we were able to show that TGF- $\beta$-R2 expression in the stroma is an independent prognostic factor. Main effector cells for TGF- $\beta 1$ in tumour-associated stroma are fibroblasts and myofibroblasts and decrease of TGF- $\beta$ receptor expression in stroma as in epithelial tumour tissue might occur via mutation or downregulation [20,21] and reflects functional alteration of TGF- $\beta$ signalling. Paracrine effects of TGF- $\beta$ in the stroma can be summarized as locally tumour promoting and implicate stimulation of angiogenesis, escape from immunosurveillance and recruitment of myofibroblasts (as reviewed in [46]). As in models of tumour escape from chemotherapy[47], disruption of TGF- $\beta$ signalling in the stroma via decreased receptor expression might drive tumour evolution towards a prometastatic phenotype. This might account for decreased survival, although other mechanisms, e.g. reduction of indirect antiproliferative TGF- $\beta$ feedback effects from stroma to tumour, are conceivable.

\section{Conclusion}

In summary not only mutational incidents in tumour cells but also interaction of tumour tissue with inflammatory cells like macrophages and associated stroma through TGF- $\beta$ signalling modulates histological phenotype and clinical progression in colorectal cancer. Further studies are needed to clarify the underlying mechanisms.

\section{Competing interests}

The author(s) declare that they have no competing interests.

\section{Authors' contributions}

DB carried out assembly of tissue micro arrays and immunohistochemical stainings including evaluation and was involved in preparation of the manuscript. RC participated in the design of the study and was responsible for collection of clinical data. TP participated in the design of the study and coordination and helped to draft the manuscript. SM participated in the design of the study and performed the statistical analysis. WB participated in the design of the study and selection of patients. AD conceived of the study, and participated in its design and coordination and helped to draft the manuscript. All authors read and approved the final manuscript.

\section{Additional material}

\section{Additional file 1}

Smad3 and Smad4 expression in tumour. The figure shows examples of immunohistochemical stainings of Smad3 and Smad 4 in tissue micro arrays. Tumours with loss of Smad4 expression were not found. Click here for file

[http://www.biomedcentral.com/content/supplementary/14712407-7-156-S1.jpeg] 


\section{Acknowledgements}

The excellent technical assistance of Alexandra Geiger and Claudia Winkelmann is greatly acknowledged. The authors thank Gertrud Zimmermann for fruitful discussions and her unweary support of the study.

\section{References}

I. Balkwill F, Mantovani A: Inflammation and cancer: back to Virchow? Lancet 200I, 357(9255):539-545.

2. Coussens LM, Werb Z: Inflammation and cancer. Nature 2002, 420(69 I 7):860-867.

3. Leek RD, Lewis CE, Whitehouse R, Greenall M, Clarke J, Harris AL: Association of macrophage infiltration with angiogenesis and prognosis in invasive breast carcinoma. Cancer Res 1996, 56(20):4625-4629.

4. Bingle L, Brown NJ, Lewis CE: The role of tumour-associated macrophages in tumour progression: implications for new anticancer therapies. I Pathol 2002, I 96(3):254-265.

5. Coussens LM, Werb Z: Inflammatory cells and cancer: think different! J Exp Med 200I, 193(6):F23-6.

6. Mantovani A, Bottazzi B, Colotta F, Sozzani S, Ruco L: The origin and function of tumor-associated macrophages. Immunol Today 1992, 13(7):265-270.

7. Ohno S, Inagawa H, Dhar DK, Fujii T, Ueda S, Tachibana M, Suzuki $N$ Inoue M, Soma G, Nagasue N: The degree of macrophage infiltration into the cancer cell nest is a significant predictor of survival in gastric cancer patients. Anticancer Res 2003, 23(6D):5015-5022.

8. Kataki A, Scheid P, Piet M, Marie B, Martinet N, Martinet Y, Vignaud JM: Tumor infiltrating lymphocytes and macrophages have a potential dual role in lung cancer by supporting both hostdefense and tumor progression. J Lab Clin Med 2002, I 40(5):320-328.

9. Nakayama $Y$, Nagashima N, Minagawa N, Inoue $Y$, Katsuki T, Onitsuka K, Sako T, Hirata K, Nagata N, Itoh H: Relationships between tumor-associated macrophages and clinicopathological factors in patients with colorectal cancer. Anticancer Res 2002 22(6C):429|-4296.

10. Roberts AB, Anzano MA, Wakefield LM, Roche NS, Stern DF, Sporn $M B$ : Type beta transforming growth factor: a bifunctional regulator of cellular growth. Proc Natl Acad Sci U S A 1985, 82(I): $119-123$.

II. Massague J: TGF-beta signal transduction. Annu Rev Biochem 1998, 67:753-79|.

12. Derynck R, Feng XH: TGF-beta receptor signaling. Biochim Biophys Acta 1997, I333(2):FI05-50.

13. Ko TC, Beauchamp RD, Townsend CMJr., Thompson EA, Thompson JC: Transforming growth factor-beta inhibits rat intestinal cell growth by regulating cell cycle specific gene expression. Am J Surg 1994, 167(I): 14-9; discussion 19-20.

14. Ko TC, Sheng HM, Reisman D, Thompson EA, Beauchamp RD: Transforming growth factor-beta $I$ inhibits cyclin $D I$ expression in intestinal epithelial cells. Oncogene 1995, 10(1): 177-184.

15. Conery AR, Cao Y, Thompson EA, Townsend CM Jr., Ko TC, Luo K: Akt interacts directly with Smad3 to regulate the sensitivity to TGF-beta induced apoptosis. Nat Cell Biol 2004, 6(4):366-372.

16. Derynck R, Akhurst RJ, Balmain A: TGF-beta signaling in tumor suppression and cancer progression. Nat Genet 200I, 29(2): $117-129$.

17. Akhurst RJ, Derynck R: TGF-beta signaling in cancer--a doubleedged sword. Trends Cell Biol 200I, I I (I I):S44-5 I.

18. Robson H, Anderson E, James RD, Schofield PF: Transforming growth factor beta $I$ expression in human colorectal tumours: an independent prognostic marker in a subgroup of poor prognosis patients. Br j Cancer 1996, 74(5):753-758.

19. Friedman E, Gold LI, Klimstra D, Zeng ZS, Winawer S, Cohen A: High levels of transforming growth factor beta I correlate with disease progression in human colon cancer. Cancer Epidemiol Biomarkers Prev 1995, 4(5):549-554.

20. Wang J, Han W, Zborowska E, Liang J, Wang X, Willson JK, Sun L, Brattain MG: Reduced expression of transforming growth factor beta type I receptor contributes to the malignancy of human colon carcinoma cells. I Biol Chem 1996, 27I(29): 17366-I737I.

21. Matsushita M, Matsuzaki K, Date M, Watanabe T, Shibano K, Nakagawa T, Yanagitani S, Amoh Y, Takemoto H, Ogata N, Yamamoto C,
Kubota Y, Seki T, Inokuchi H, Nishizawa M, Takada H, Sawamura T, Okamura A, Inoue K: Down-regulation of TGF-beta receptors in human colorectal cancer: implications for cancer development. Br J Cancer 1999, 80( I-2): 194-205.

22. Riggins G], Thiagalingam S, Rozenblum E, Weinstein CL, Kern SE, Hamilton SR, Willson JK, Markowitz SD, Kinzler KW, Vogelstein B: Mad-related genes in the human. Nat Genet 1996, 13(3):347-349.

23. Eppert K, Scherer SW, Ozcelik H, Pirone R, Hoodless P, Kim H, Tsui LC, Bapat B, Gallinger S, Andrulis IL, Thomsen GH, Wrana JL, Attisano $L$ : MADR2 maps to $18 \mathrm{q} 21$ and encodes a TGFbeta-regulated MAD-related protein that is functionally mutated in colorectal carcinoma. Cell 1996, 86(4):543-552.

24. Thiagalingam S, Lengauer C, Leach FS, Schutte M, Hahn SA, Overhauser J, Willson JK, Markowitz S, Hamilton SR, Kern SE, Kinzler KW, Vogelstein B: Evaluation of candidate tumour suppressor genes on chromosome 18 in colorectal cancers. Nat Genet 1996, I3(3):343-346.

25. Takagi $Y$, Kohmura H, Futamura M, Kida H, Tanemura H, Shimokawa $\mathrm{K}$, Saji S: Somatic alterations of the DPC4 gene in human colorectal cancers in vivo. Gastroenterology 1996, III(5):I369-1372.

26. MacGrogan D, Pegram M, Slamon D, Bookstein R: Comparative mutational analysis of DPC4 (Smad4) in prostatic and colorectal carcinomas. Oncogene 1997, I 5(9): I II I-I I I4.

27. Gordon S: Alternative activation of macrophages. Nat Rev Immunol 2003, 3(I):23-35.

28. Mantovani A, Sozzani S, Locati M, Allavena P, Sica A: Macrophage polarization: tumor-associated macrophages as a paradigm for polarized M2 mononuclear phagocytes. Trends Immunol 2002, 23(I I):549-555.

29. Crowther M, Brown NJ, Bishop ET, Lewis CE: Microenvironmental influence on macrophage regulation of angiogenesis in wounds and malignant tumors. I Leukoc Biol 200I, 70(4):478-490

30. Pollard JW: Tumour-educated macrophages promote tumour progression and metastasis. Nat Rev Cancer 2004, 4(I):7I-78.

3I. Nesbit M, Schaider H, Miller TH, Herlyn M: Low-level monocyte chemoattractant protein-I stimulation of monocytes leads to tumor formation in nontumorigenic melanoma cells. J Immunol 200I, 166(I I):6483-6490.

32. Dinapoli MR, Calderon CL, Lopez DM: The altered tumoricidal capacity of macrophages isolated from tumor-bearing mice is related to reduce expression of the inducible nitric oxide synthase gene. J Exp Med 1996, I 83(4): I 323-1329.

33. Oosterling SJ, van der Bij GJ, Meijer GA, Tuk CW, van Garderen E, van Rooijen N, Meijer S, van der Sijp JR, Beelen RH, van Egmond M: Macrophages direct tumour histology and clinical outcome in a colon cancer model. J Pathol 2005, 207(2): I47-I55.

34. Tsamandas AC, Kardamakis D, Ravazoula P, Zolota V, Salakou S, Tepetes K, Kalogeropoulou C, Tsota I, Kourelis T, Makatsoris T, Karavias D, Scopa CD, Bonikos DS, Kalofonos HP, Petsas T: The potential role of TGFbetal, TGFbeta2 and TGFbeta3 protein expression in colorectal carcinomas. Correlation with classic histopathologic factors and patient survival. Strahlenther Onkol 2004, 180(4):20I-208.

35. Guzinska-Ustymowicz K, Kemona A: Transforming growth factor beta can be a parameter of aggressiveness of pTI colorectal cancer. World J Gastroenterol 2005, I I (8): I | 93- I I95.

36. Bellone G, Carbone A, Tibaudi D, Mauri F, Ferrero I, Smirne C, Suman F, Rivetti C, Migliaretti G, Camandona M, Palestro G, Emanuelli G, Rodeck U: Differential expression of transforming growth factors-beta I, -beta2 and -beta 3 in human colon carcinoma. Eur J Cancer 200I, 37(2):224-233.

37. Kouraklis G, Kakisis J, Theoharis S, Tzonou A, Glinavou A, Raftopoulos J, Karatzas G: Prognostic significance and correlation with survival of bcl-2 and TGF-beta RII in colon cancer. Dig Dis Sci 2003, 48( ( 2 2):2284-2289.

38. Schwarte-Waldhoff I, Schmiegel W: Smad4 transcriptional pathways and angiogenesis. Int / Gastrointest Cancer 2002, 3 I(I3):47-59.

39. Tang Y, Katuri V, Srinivasan R, Fogt F, Redman R, Anand G, Said A Fishbein T, Zasloff M, Reddy EP, Mishra B, Mishra L: Transforming growth factor-beta suppresses nonmetastatic colon cancer through Smad4 and adaptor protein ELF at an early stage of tumorigenesis. Cancer Res 2005, 65(1 0):4228-4237. 
40. Isaksson-Mettavainio M, Palmqvist R, Forssell J, Stenling R, Oberg A: SMAD4/DPC4 expression and prognosis in human colorectal cancer. Anticancer Res 2006, 26(IB):507-5I0.

4I. Xie W, Rimm DL, Lin Y, Shih WJ, Reiss M: Loss of Smad signaling in human colorectal cancer is associated with advanced disease and poor prognosis. Cancer / 2003, 9(4):302-3/2.

42. Alazzouzi $H$, Alhopuro $P$, Salovaara $R$, Sammalkorpi $H$, Jarvinen $H$, Mecklin JP, Hemminki A, Schwartz S Jr., Aaltonen LA, Arango D: SMAD4 as a prognostic marker in colorectal cancer. Clin Cancer Res 2005, I I (7):2606-26 I I.

43. Maitra A, Molberg K, Albores-Saavedra J, Lindberg G: Loss of Dpc4 expression in colonic adenocarcinomas correlates with the presence of metastatic disease. Am J Pathol 2000, | 57(4): I 105-IIII.

44. Kouvidou C, Latoufis C, Lianou E, Kouvatseas G, Kakouri E, Anagnostakis D, Vrettou-Aravani V, Betsi E, Karatapanis S: Expression of Smad4 and TGF-beta2 in colorectal carcinoma. Anticancer Res 2006, 26(4B):290I-2907.

45. Deacu E, Mori Y, Sato F, Yin J, Olaru A, Sterian A, Xu Y, Wang S, Schulmann K, Berki A, Kan T, Abraham JM, Meltzer SJ: Activin type II receptor restoration in ACVR2-deficient colon cancer cells induces transforming growth factor-beta response pathway genes. Cancer Res 2004, 64(2I):7690-7696.

46. De Wever O, Mareel M: Role of tissue stroma in cancer cell invasion. J Pathol 2003, 200(4):429-447.

47. Michor F, Nowak MA, Iwasa Y: Evolution of resistance to cancer therapy. Curr Pharm Des 2006, I2(3):26I-27I.

\section{Pre-publication history}

The pre-publication history for this paper can be accessed here:

http://www.biomedcentral.com/1471-2407/7/156/pre pub

Publish with Biomed Central and every scientist can read your work free of charge

"BioMed Central will be the most significant development for disseminating the results of biomedical research in our lifetime. "

Sir Paul Nurse, Cancer Research UK

Your research papers will be:

- available free of charge to the entire biomedical community

- peer reviewed and published immediately upon acceptance

- cited in PubMed and archived on PubMed Central

- yours - you keep the copyright 